\title{
From West to East and Back Again: Faith, Doubt and Education in Hermann Hesse's Later Work
}

\section{PETER ROBERTS}

This paper examines Hermann Hesse's penultimate novel, The Journey to the East, from an educational point of view. Hesse was a man of the West who turned to the idea of 'the East' in seeking to understand himself and his society. While highly critical of elements of Western modernism, Hesse nonetheless viewed 'the East' through Western lenses and drew inspiration from other Western thinkers. At the end of The Journey to the East, the main character, H.H., believes he has found the solution to his despair. This paper argues that he has not, at least not in the fullest sense Hesse came to see was possible. H.H. relies too heavily on faith and abandons reason too quickly in seeking to become 'absorbed' into the Other he regards as his higher self. An answer to H.H.'s existential angst can be found in Hesse's final novel, The Glass Bead Game, where educational growth through the development of a critical, questioning, inquiring attitude is a central theme.

\section{INTRODUCTION}

Over the past two decades, a number of philosophers of education have considered the potential value of literature in addressing ethical, epistemological and ontological questions (e.g., Barrow, 2004; Carr, 2005; Katz, 1997; Jollimore and Barrios, 2006; Roberts, 2005, 2007; Sichel, 1992; Siegel, 1997; Zigler, 1994). It has long been recognised that novels and other literary works can play a distinctive role in moral development (Cunningham, 2001; Nussbaum, 1990; Palmer, 1992; Weston, 2001) and the education of the emotions (Gribble, 1983; Hepburn, 1972; Solomon, 1986). The contribution of literature to the enhancement of reason, within both public and private domains, has also been acknowledged (Novitz, 1987; Nussbaum, 1995; Siegel, 1997). For Nussbaum (1990), reading literary works is one of the ways we constitute ourselves as moral and fully human beings. Interpreting a novel involves 'a kind of sympathetic reasoning that is highly characteristic of morality; for we ask ourselves, as we try to enter into the plot, why the characters do what they do, and we are put off if our inquiries lead to nothing but mystery and arbitrariness' (Nussbaum, 1990, p. 346). Literature allows us to develop a form of ethical understanding 'that involves emotional as well as intellectual activity and gives a certain type of priority to the perception of particular people and situations, rather than to abstract rules' (p. ix). As Jollimore and Barrios (2006) put it, '[t]he great advantage of literature, as a tool for the cultivation of virtue, is precisely that it allows for the complexities of moral reality to be depicted and investigated' (p. 381). This point finds further elaboration in the 
work of Katz (1997), who observes that in good novels, we find not abstract moral agents but three-dimensional, complex characters in 'dense, richly contextualized human situations, situations that lend themselves to multiple interpretations' (p. 8).

Given this philosophical and educational interest in literature, it is, I want to suggest, timely to revisit the work of the German Nobel laureate, Hermann Hesse. Hesse was born in Calw in 1877 and died in 1962. His family had strong theological commitments, and it was expected that Hermann would follow in their footsteps. Hesse was an exceptionally bright student, but he rebelled against authority and did not have happy memories of his time in school. He rejected the plans others had for him, having vowed from his thirteenth year to become 'a poet or nothing at all' (Helt, 1996). He worked for periods as a mechanic and bookseller before devoting himself completing to writing. A staunch opponent of the Nazi regime, Hesse spent much of his life in Switzerland. There he composed many of the books for which he has become best known: Siddhartha (Hesse, 2000a), Steppenwolf (Hesse, 1965), Narcissus and Goldmund (Hesse, 1968a), and The Glass Bead Game (Hesse, 2000b). Hesse was also a prolific reviewer, esssayist and short story writer (Hesse, 1973, 1974a, 1974b, 1978, 1982). He commented critically and at length on the world wars of the first half of the twentieth century (Hesse, 1974c) and was an accomplished poet and artist (see Hesse, 1970, 1985). A number of Hesse's novels and stories address educational themes. Beneath the Wheel (Hesse, 1968b), for example, focuses on the distressing school and examination experiences of a young scholar; Demian (Hesse, 1999) explores the relationship between Emil Sinclair and a fellow student, Max Demian; Siddhartha (Hesse, 2000a) depicts a process of learning and spiritual growth through the central character's different modes of life; and The Glass Bead Game (Hesse, 2000b) is set in Castalia, a 'pedagogical province' of the future. It is thus a matter for some surprise that so little attention has been paid to Hesse's work by educationists. There are rare exceptions (e.g., Peters, 1996; Sears, 1992; Roberts, 2007), but on the whole Hesse seems to have been largely ignored. There was intense interest in his work in the United States and other English speaking countries in the late 1960s and 1970s, particularly among younger readers, alternative lifestylers and counter cultural thinkers (Gropper, 1970, 1972; Schwarz, 1970; Timpe, 1969). In more recent years, with the rise of the Internet, artificial intelligence systems, and other digital technologies there has been a renewed appreciation of Hesse's prophetic thinking in The Glass Bead Game (Leary, 1986; Peters, 1996; Wands, 1999).

Hesse's relevance for educationists lies not just in his overt focus on schooling and other forms of institutional education but in his broader investigation, through his literary work, of processes of human growth and development. Hesse can be seen as one of the key figures in the evolution of the German Bildungsroman. Bildung as a form of individual self-realisation occupies a central place in the German literary and philosophical tradition. Goethe, Schiller and Humboldt, among others, were concerned to counter what they saw as a worrying trend toward narrowness and specialisation. The genesis of the Bildungsroman lies in the changing historical circumstances of late $18^{\text {th }}$ century Germany and represents a humanistic response to the growth of science and materialism. Swales (1978, p. 12) notes that the term Bildungsroman was first coined by Karl Morgenstern in the early 1820s. For Morgenstern, the Bildungsroman both portrayed the Bildung of the novel's central character and enhanced the Bildung of the reader (to a significantly greater extent than any other kind of novel). It was Wilhelm Dilthey's approach in the late $19^{\text {th }}$ century, however, that has been most influential. Dilthey depicted the Bildungsroman in this manner: 
A regulated development within the life of the individual is observed, each of its stages has its own intrinsic value and is at the same time the basis for a higher stage. The dissonances and conflicts of life appear as the necessary growth points through which the individual must pass on hiw way to maturity and harmony. (cited in Swales, 1978, p. 3)

Swales points to some of the limits of this definition (and other analyses premised on it), drawing attention to the danger that the Bildungsroman can come to be seen as little more than a vehicle for conveying the author's ideas about personal growth - a 'discursive essay in the aesthetic mode, whereby the plot, the events chronicled, are relegated to the level of contingent illustrative material' (p. 4). This denies the complexity and significance of human experience. As Swales (1978) points out, the major novels of the Bildungsroman tradition are not merely allegories of inner life:

Practical reality continues to impinge on the cherished inwardness of the hero, and precisely this process is the source of the irony, the obliqueness, the uncertainty which so many commentators have noticed. It is, moreover, the same process that makes the "learning from life" which the hero undergoes such a tentative progression. Over and over again, the novels themselves pose the question of whether the hero has achieved any kind of worthwhile goal or insight. The notion of organic growth, of a maturing process that somehow eludes even conceptual terms, is a difficult one to pinpoint in terms of unequivocal narrative realization. Perhaps we are essentially concerned with an article of faith that seeks to assert the reconcilability of human wholeness on the one hand and the facts of limited and limiting social experience on the other. (Swales, 1978, p. 30)

Swales observes that while a certain skepticism about the law of linear experience is characteristic of the Bildungsroman genre, the best authors in this tradition nonetheless remain true to the novel form and do not confuse their art with the writing of philosophical treatises. Part of the role of the Bildungsroman is to remind us that we have all have a story to tell, and that while we can question and wrestle with what life throws at us, we cannot halt the flow of experience. It is, as Swales puts it, 'the story which binds together contingencies into the weighty sequence of a human destiny' (1978, p. 33). The Bildungsroman allows the novel to consider experience not as something fixed and final. The meaning of growth - of formation and development - depicted in exemplary works in this tradition lies not so much in the goals set by the central characters as in the process through which such goals are pursued:

The grasping for clarity and losing it, the alteration of certainty of purpose with a sense of the overriding randomness of living, these are seen to be the very stuff of human experience and such meaning and distinction as men are able to attain. The Bildungsroman, then, is written for the sake of the journey, and not for the sake of the happy ending toward which that journey points. (Swales, 1978, p. 34)

Swales argues that the best Bildungsromanae occupy 'the awkward middle ground between wholeness and constriction, between possibility and actuality'. This tension is an expression of the 'moral and spiritual uncertainties at the heart of bourgeios society, of an allegience to practical reality and to that creative transcendence vouchsafed by the individual's inwardness' (1978, p. 158).

Swales' comments provide an ideal backdrop against which to consider Hesse's penultimate novel, The Journey to the East (Hesse, 1956). For in this short literary work can be found, in germinal form, many of the features of the Bildungsroman described by Swales: the idea of an inner or spiritual journey, the tension between the 
possible and the actual, and the importance of context in character formation. This paper considers The Journey to the East from an educational point of view. The first section provides a brief summary of the book and discusses the meaning of 'the East' in Hesse's work. Hesse, it will be suggested, was a man of the West who turned to the idea of the 'the East' in seeking to understand himself and his society. Hesse was strongly opposed to elements of Western modernism, yet he also contributed to the development of the modernist novel and wrote prophetically about modernist - and postmodernist - intellectual and cultural futures. In pondering the future of humanity, he drew inspiration from the work of Nietzsche and Dostoevsky, and the influence of both of these thinkers is evident in his fiction.

The second section turns to more specifically educational concerns and addresses the last part of The Journey to the East in some detail. I take the position that if The Journey to the East is to be understood, it must be read alongside The Glass Bead Game (Hesse, 2000b). The Glass Bead Game, when read in conjunction with The Journey to the East, provides further evidence of Hesse's distinctive contribution to the German tradition of the Bildungsroman. The Glass Bead Game takes further those elements of the Bildungsroman that matter most for Hesse - striving, uncertainty, complexity, and transformation - and makes their significance for educational theory more overt. The Journey to the East poses an existential problem for which an educational 'answer' is to be found in The Glass Bead Game. The Journey to the East leaves the central character, H.H., believing he has re-discovered the purpose of his existence. I argue that he has not - at least not in the fullest sense Hesse came to see was possible. H.H.'s resolution to his despair relies on faith and uncritical 'absorption' into the 'Other' he comes to see as his higher self. H.H. abandons reason too quickly and fails to appreciate the importance of education in human development and understanding. The Journey to the East does not adequately address the importance of questioning, dialogue and doubt in spiritual striving. These are key features of Joseph Knecht's educational formation and growth as a human being. Hesse thus provides, in The Glass Bead Game, an effective critique of his earlier novel.

\section{EAST AND WEST IN HESSE'S WORK}

The Journey to the East (Hesse, 1956) serves as an important bridging work in Hesse's corpus of published writings. It builds on the philosophical foundation laid by novels such as Siddhartha (Hesse, 2000a) and Steppenwolf (Hesse, 1965) while hinting at ideas that were later to find fuller expression in The Glass Bead Game (Hesse, 2000a). Middleton (1957) sees the book as a turning point in Hesse's work. In The Journey to the East Hesse recreates and integrates themes and figures from his earlier novels and thereby provides 'a concise verbal representation of the essentials of his own mental history' (p. 309). At a little over 100 pages, The Journey to the East is Hesse's shortest novel. The book has a deceptively simple narrative structure. Much of the first half of the novel is taken up with the dream-like reflections of H.H., the narrator and main character, who looks back on his time with a group of Journeyers to the East. The goals, composition and itinerary of the group remain somewhat vague, but it is made clear that they travelled widely, not just in space but in time. The group is but one among many in the League of Journeyers. H.H. regards his time with the group as the high point of his life and he wishes to write a history of the League. He struggles to get to grips with this task, however, having fallen into 
despair following the dissolution of his group. The trigger for the group's disintegration, it turns out, was the disappearance of a servant, Leo. With this seemingly innocuous event, the group loses its cohesion, lapsing into petty squabbles and exaggerated anxiousness over the apparent loss of small personal articles.

The action in the second half of the book is centred more on the present. H.H. visits Lukas, an old friend, and discusses his difficulties with him. Lukas is himself scarred psychologically from the war (World War I) but tells H.H. that writing became for him a necessity in dealing with his troubled memories. Lukas comes to see that Leo is a 'problem' for H.H. and that the solution to his difficulties lies in confronting this and ridding himself of him. Lukas and H.H. discover a Leo in the city directory, and H.H. seeks him out. Eventually H.H. speaks with Leo, the latter not recognising him. After their strange encounter, Leo calls on H.H. and takes him via a labyrinthine path to a large building, where H.H. undergoes an elaborate confession. He learns that the League, far from having disappeared, is as strong as ever and that Leo is its President. H.H. comes to see that it was he who deserted the League, not the League that had abandoned him. He admits to his failings, in front of a large gathering of League members, and is required to read the files held about him in the archives of the building. This proves to be a pivotal moment in the book. H.H. finds little written information; instead, there is a small two-part figure, joined at the back. One part of the figure, H.H. believes, is intended to represent himself, the other part Leo. The H.H. half is ailing, while the Leo half is strong and healthy. H.H. concludes that over time the substance from one image will flow into the other and only one will remain; he must disappear, while the Leo half must grow.

Despite its title, the book is, in some respects, a step away from the East - or at least the East as this had been represented in Siddhartha (Hesse, 2000a). With The Journey to the East Hesse arguably takes a step back towards the West. The West to which Hesse is returning is more multilayered and complex than the version depicted in some of his earlier works, but he does not quite reach this in The Journey to the East. It is in The Glass Bead Game, published more than a decade after The Journey to the East, that Hesse's most reflexive and mature representation of the West can be found. There, 'the West', with its possibilities as well as limitations, finds fuller exploration with the establishment of Castalia - an intellectual community of the future - in the wake of a Europe left in ruins by the wars of the first half of the $20^{\text {th }}$ century. The Glass Bead Game is, to be sure, dedicated to 'The Journeyers to the East', but 'the East' here must, I think, be interpreted more as a symbolic ideal than a place or set of places.

This view of 'the East' is already present, but in more vaguely developed form, in The Journey to the East. H.H. notes early on his narration that shortly after being admitted to the League, one of its secrets immediately became clear to him:

I realized that I had joined a pilgrimage to the East, seemingly a definite and single pilgrimage but in reality, in its broadest sense, this expedition to the East was not only mine and now; this procession of believers and disciples had always and incessantly been moving towards the East, towards the Home of Light. Throughout the centuries it had been on the way, towards light and wonder, and each member, each group, indeed our whole host and its great pilgrimage, was only a wave in the eternal stream of human beings, of the eternal strivings of the human spirit towards the East, towards Home. (pp. 12-13)

'The East', then, is home. In the book, the words of the poet Novalis (an important influence on Hesse's work) are quoted directly: 'Where are we really going?' asks Novalis; 'Always home!' (p. 13). But 'home' for Hesse was, in one sense at least, the 
West. Hesse was a Westerner by birth and, while he did make his own pilgrimage to the East (with a trip to India in 1911), he remained a Westerner throughout his life. After leaving a Germany ravaged by what he saw a kind of social and cultural madness, he sought refuge in Switzerland. There, in comparatively peaceful surroundings, he was able to compose the books that would later bring him international attention. These included the novels that would have an overt focus on 'the East'. Hesse was influenced in his childhood years by his family's experiences of the East (his father and one of his grandfathers served as Protestant missionaries in India), but he attended Western schools, spoke a Western language, and became as steeped in Western culture and traditions as other talented boys of his age.

For Hesse, 'the East' can be seen as the end toward which we all strive. Thus conceived, the East becomes a universal human destination: a vocation, if you like, to be pursued in different ways by various individuals and groups who are nonetheless united by the very fact that they seek something more - something higher or better for themselves. It is the quest itself - the process of seeking - that is universal, even if the ways in which this is followed will differ. Hesse's personal quest was inevitably shaped by his immersion in the ways of the West, even as he railed against elements of this at different points throughout his life.

Hesse found himself very much at odds with the new German reality in the years following the first World War. Believing the decline of the West was 'fated, irreversible, and complete' (Antosik, 1978, p. 63), Hesse saw an emerging age of catastrophes and nihilism. Soon, he felt, 'all Western Europe would succumb to wars, revolutions, and moral insanity’ (p. 63).

Proclaiming himself an enemy of the modern world, he became one of the fiercest anti-modernists of the decade. Whatever belonged to modernity, whether it was the automobile, modern architecture, mass-production, or the prosperity of the 1920's, received short shrift in his writings. Europe, he said, was on the threshold of a dehumanized "machine-culture" that could benefit only the masses who were too stupid to see how cheap and ugly modern life really was. Both present and future could, on this view, offer mankind nothing but a collectivized existence devoid of spirit. And the prospect filled Hesse with such rage that at times he wished to see modern Europe annihilated by machines run amuck or in a second world war. (p. 65)

Hesse's disgust with contemporary Western civilization, and specifically with post First World War Germany, led him to turn, on the one hand, to the East and, on the other, to the Europe of the Middle Ages. Antosik argues that Hesse supported the emergence of an elite 'secret priesthood' of artists and intellectuals who would be 'oblivious to the pressures of society and devoted to the preservation of European culture' (pp. 66-67). In the years from 1916 to 1922, Hesse's cultural elitism took an anti-European and demonic form, as expressed in works such as Demain (Hesse, 1999). By the end of 1920s, however, Hesse had returned to 'what he regarded as his true home within himself and the European tradition' (Antosik, 1978, p. 63). He remained an anti-modernist throughout, but his manner of expressing this shifted over time.

Anti-modernist tendencies of a certain kind are clearly evident in The Journey to the East. H.H. notes that his group of Journeyers 'lived like pilgrims and made no use of those contrivances which spring into existence in a world deluded by money, number and time, and which drain life of its content; mechanical contrivances such as railways, watches and the like came chiefly into this category' (Hesse, 1956, pp. 1314). The Glass Bead Game, despite being set in the $23^{\text {rd }}$ century, has very little to say about new technological developments. There are occasional references to the use of 
radios, loudspeakers, and other devices in Castalia, but there is nothing that might resemble the futuristic portraits of everyday life found in many utopian or dystopian works of science fiction. Even automobiles barely warrant a mention, and most Castalians seem to prefer to travel by foot. Hesse's aversion to modern technologies is evident in a number of his short stories as well (see Hesse, 1974b), with machines sometimes occupying a central place in nightmarish scenarios.

Yet, as Norton (1968) points out, Hesse's concern lay not so much with the machines and gadgets themselves as with the dehumanising consequences of relying too heavily on them. Antosik is right, I think, to cast Hesse as anti-modernist in his attitude toward machinic culture, but Hesse was still shaped by his age and to some extent complicit in its successes and failures. Hesse looked backwards to pre-modern periods in human history for literary, philosophical and spiritual inspiration. In The Journey to the East, there are references to thinkers from antiquity to the Middle Ages, and in The Glass Bead Game the origins of the Game itself are said to lie deep within human history. Hesse attempted to recover what he saw as noble and worthwhile in the culture and thought of the past, but he did so wearing modern lenses. The very form taken by some his novels owes much to modernism (cf. Peters, 1996). Hesse can be seen as an innovator within the romantic tradition of the modern novel, and he has been compared with other modernist writers such as James Joyce. Spivey (1970), for example, notes that '[b]oth Joyce and Hesse have for too long been seen by older critics as artists who present visions of the modern fragmentation of life' (p. 50). It is true, Spivey concedes, that novels such as Ulysses (Joyce, 1990) and Steppenwolf (Hesse, 1965) 'present profound visions of the break-up of modern life, of the gradual fragmenting of all social forms and of the dissolution of the soul' (Spivey, 1970, p. 50). The fragmented modern world, however, 'is but the scene, the wasteland setting, for the journey of a quester who seeks a new life, and who, because of his quest is shown moving toward new life' (p. 50).

Hesse may have looked to the past for answers to what he saw as some of the deepest problems facing human beings in the $20^{\text {th }}$ century, but both The Journey to the East and The Glass Bead Game point, prophetically, to changes that lie ahead (cf. Peters, 1996; Wilde, 1999). Hesse's contribution does not lie in the sophistication of his imaginary portraits of new machines, biological technologies, transport systems, or monitoring devices. Rather, it is his clarity in detecting the cultural and intellectual shifts that would give rise to these technological developments that marks him out as a man ahead of his time. He was not alone in this, of course. Two of the writers and thinkers Hesse admired most were Dostoevsky ${ }^{1}$ and Nietzsche ${ }^{2}$ (see Hesse, 1974c, 1978), and in their work he could see the foreshadowing of what he regarded as a frightening future.

The Journey to the East poses searching questions about the nature of truth, appearing at first glance to answer them with modernist or pre-modernist certainty (e.g., in the form of universalist, if mysterious, League goals), yet also leaving some room for doubt. Through the very construction of a narrative of almost exaggerated certainty in the League's rituals and requirements for faith, Hesse invites readers to question, to read against what is represented by Leo and the League. In some parts of the novel, this invitation becomes somewhat more explicit. Near the end of the lengthy first chapter, for instance, H.H. reflects on the challenge facing any historian seeking to record, honestly and accurately, the events of a period. 'Where', he asks, 'is the center of events, the common standpoint around which they revolve and which gives them cohesion?' (p. 47). To create some kind of cohesion, causality, and meaning the historian 'must invent units, a hero, a nation, an idea, and he must allow 
to happen to this invented unit what has in reality happened to the nameless' (p. 47). Connecting events and relaying them to others is made even more difficult in H.H.'s case, 'for everything becomes questionable as soon as I consider it closely, everything slips away and dissolves, just as our community, the strongest in the world, has been able to dissolve' (pp. 47-48). 'There is', he concludes, 'no unit, no center, no point around which the wheel revolves' (p. 48). While this does not amount, in itself, to a sophisticated critique of modernist certainty, it does prefigure some of the concerns that would later preoccupy postmodernists: the idea that 'truth' might be contested, the elusive character of meaning, and the loss of a 'centre' around which everything else (e.g., moral prescriptions, truth claims, a purpose for life) might revolve.

The book places considerable emphasis, explicit and implicit, on the significance of ideas - or, to be more precise, on the importance of the realm of ideas. Plato is listed as one of the brothers in the long history of the League (p. 55), and there are echoes of Platonism throughout the book. Plato's theory of Forms, in particular, seems to serve as an invisible foundation on which much of the philosophical discussion in the book (such as it is) proceeds. It is, the book seems to suggest, ideas that matter more than the physical manifestations of those ideas. There is a realm of ideas that transcends the particulars of context and circumstance. Those who think, who create, are merely participants in this universal realm. As H.H. notes in the penultimate paragraph of the novel, the creations of poetry can be seen as 'more vivid and real than the poets themselves' (p. 118). H.H., to carry the comparison with Plato further, might be seen as moving forwards towards the light, but by the end of the novel he still has some way to go before reaching the front of the cave (cf. Plato, 1974).

H.H.'s journey to the East is a journey not so much in space, or even in time as conceived in the everyday ('tick tock') sense, but in consciousness. Crenshaw and Lawson (1972) see The Journey to the East as a kind of 'fairy tale', noting that this literary form allows for unusual changes and permutations in time. They observe that just as actual and fictitious places are mixed in The Journey to the East, so too is the element of time neither real nor unreal. 'The transcending of chronological time and the compromising - if not ignoring - of logic', Crenshaw and Lawson suggest, 'may well be a more successful technique for describing existence than is the use of logical consequence. It would, accordingly, seem well adapted to the subtle and effective expression of a philosophy' (p. 54).

The East, for H.H. and for Hesse himself, is an idea toward which seekers travel in their own distinctive ways. The East, as 'the Home of Light' (Hesse, 1956, p. 13), is where we are all headed and H.H.'s journey in consciousness is in this direction, even if he is unaware of it during the long years following the dissolution of his group in the League. At least, this is what seems to be suggested by the end of the novel. There is a resolution of sorts in the final part of the book, and H.H. appears to believe he has solved the riddle to understanding himself. I want to suggest that he has not. H.H.'s revelation relies on faith. What is needed, I shall argue, is a more overtly educational approach to addressing his despair and to seeking self-understanding: a resolution that values rather than rejects questioning and uncertainty.

\section{FAITH, DOUBT AND EDUCATION}

Hesse was not a follower of any one religion or philosophical tradition. He did not see himself as a disciple of any guru. He wished to uphold the integrity of the 
individual and was suspicious of any movement that demanded a complete surrendering of the 'self' to others or to a cause. The Journey to the East comes close, however, to allowing exactly this to happen. H.H. speaks of being willing to sacrifice his life for the League: 'if today or tomorrow I had to appear before a court-martial and was given the option of dying or divulging the secret of the League, I would joyously seal my vow to the League with death' (p. 5). We might grant H.H. the benefit of the doubt here and insist that this is a form of principled, reflective commitment, rather than blind adherence to League dogma. Yet, much of what happens later in the book diminishes H.H.'s ability to think critically and independently about his relationship with others in the League. H.H. has to bow down before Leo and the many others who have assembled to hear his confession, humiliate himself in front of them, and obey a series of commands if he wishes to be accepted back into the brotherhood. His absorption into Leo, symbolically, at the end of the novel seems to complete the picture of a gradual surrendering of that part of himself that had entertained doubts and uncertainties. ${ }^{3}$

The Journey to the East, more than any other book in Hesse's corpus, places great weight on the notion of faith. H.H. wants to believe in the existence of the League and in the greatness of its mission. He experiences his years in an existential wilderness following the dissolution of his group as a crisis of faith, and seeks to regain this in reacquainting himself with Leo. The book is very clear on the limits it wishes to place on reason. After recalling the tensions and arguments that emerged following Leo's apparent disappearance, H.H. resolves to persist in his task of recording his story of the League no matter what. If necessary, he says to himself, he will begin his task a hundred times, and if he continues to arrive at the same cul-desac and cannot 'assemble the pictures into a significant whole again', he will 'present each single fragment as faithfully as possible' (p. 52). He continues: 'And as far as is now still possible, I will be mindful of the first principle of our great period, never to rely on and let myself be disconcerted by reason, always to know that faith is stronger than so-called reality' (p. 52).

This passage seems to confuse 'reason' with 'reality' and in this sense leaves considerable scope for varying interpretations. It does appear, at the very least, that an incredulity toward conventional concepts of reality is evident here, reinforcing the Platonic metaphysical principles that are espoused, albeit only indirectly, elsewhere. H.H. leaves considerable ambiguity as to what he means by 'reality', but he seems to suggest there is something more to it than the physical world and the world of everyday experience. The physical world is the world of mere appearances and in this sense is 'so-called' reality only. There is, H.H. hints, a 'truer', higher reality to be found elsewhere. The League, he believes, sets us on the path to finding this higher reality, and reason alone will be an insufficient guide on our journey. His claim is, in fact, even stronger than this: faith, he wants to say, must override reason as a guiding principle on the journey.

This is where H.H.'s failure to recognise the importance of education becomes most evident. It is, I would maintain, the very qualities H.H. seeks to give up to which he should cling. The first half of the book emphasises H.H.'s doubts, his uncertainties, his willingness to question. Much of the second half of the book is concerned with the gradual replacement of these doubts with greater certainty, engendered through H.H.'s renewal of a link with Leo and, with this, the reviving of an opportunity to rejoin the fold - to regain his faith and his ability to participate again as a loyal, able brother in the Journey to the East. This represents success in one sense: H.H. finds a certain peace in confessing his 'sins' and confronting his past 
- and ultimately himself - through the archives. But it can also be seen as a form of failure - an educational failure. H.H. is willing to abandon reason and critical thought in the service of the brotherhood. In so doing, he gives up a portion of himself, the individual integrity and self-will Hesse held so dear (see, for example, Hesse, 1974c, pp. 71-76), believing the answer lies in his absorption into something higher signified by Leo.

It is as if Hesse, in this most autobiographical of his novels, is pushing himself to return to something he has lost. This is a mission that is doomed to failure. Faith, of all human qualities, is arguably the least amenable to wilful, determined encouragement. Faith cannot be recovered by force - by an effort of will - let alone by fiat or a decree issued by others. Hesse's searching, curious, questioning mind cannot be suddenly 'switched off'. This, it might be said, is one of the risks of education. Once a critical mode of being has been developed, one is changed for life. There is no going back. The nagging voice of doubt and the gentle prompting of an inquisitive, inquiring mind intrude whether they are wanted or not. Hesse, it must be remembered, had spent much of his literary career creating characters who were, in one way or another, rebels: from Hans Giebenrath in Beneath the Wheel (Hesse, 1968b), to Demian in the book of that name (Hesse, 1999), to Harry Haller in Steppenwolf (Hesse, 1965). Siddhartha even questions the original Buddha, and is unwilling to surrender himself fully, as his friend Govinda does, to the teachings of Gotama or any other single guide (see Hesse, 2000a). These characters and others in Hesse's corpus do not simply accept the rules, the ideas, the structures, the conventions prescribed by others: they resist, sometimes with tragic consequences, but often with a certain dignity and the promise of fulfilling a higher calling. The Journey to the East seems to want to impose a model of character development on H.H. that is at odds with this - and with Hesse's own inclinations.

There is a sharp contrast between The Journey to the East and The Glass Bead Game on this point. Castalia certainly places a premium on adherence to the principles of hierarchy. The individual, the narrator makes clear from the beginning of the book, is very much secondary to the Order. But Joseph Knecht does not simply accept this; he questions the very foundations on which Castalian society is based. He loves the Glass Bead Game and devotes his life to it, but he also sees limits in the Game and the social system that supports it. Knecht, while in many senses a loyal citizen of Castalia and one of its most distinguished representatives, does not merely follow the dictates of the hierarchy. He reaches the very summit of that hierarchy, attaining the position of Magister Ludi (Master of the Glass Bead Game), but comes to realise that his task later in life lies elsewhere. He sees that Castalia is already in decay. Members of the Castalian elite have little respect for history and fail to see that just as Castalia was created through the actions of real human beings in the past so too could it disappear in the future. Knecht does not abandon reason in favour of faith; he embraces it (as is clearly evident from the quality of his argument in his Circular Letter to the Board of Educators, in which he seeks approval for his decision to leave the Order) while also recognising its limits. Knecht's education is, in part, a process of coming to accept - indeed, to celebrate - uncertainty. Castalia's excessive certainty about its superiority over other forms of social organisation constitutes a form of unhealthy smugness which will, Knecht comes to see, lead to its ultimate demise.

Knecht's educational growth is prompted by his dialogical relationships with two other characters, Plinio Designori and Father Jacobus. Joseph meets Plinio during his school days and the two enter into a series of spirited debates about the strengths and 
weaknesses of Castalian society. Plinio is an outsider who has been sent by his family to study in the pedagogical province for a period in his youth. Plinio and Joseph meet up again at different points in their lives, and when Knecht decides to leave Castalia it is to tutor Plinio's son, Tito. Knecht forms an intellectual friendship with Father Jacobus when he (Knecht) is sent by the Castalian authorities on a mission to a Benedictine monastery in Mariafels. Father Jacobus is one of the monastery's most accomplished members and is an important figure in world Catholic affairs. Knecht's role is ostensibly to teach the Mariafels monks and novices about the Glass Bead Game, but he later learns that the real goal was to strengthen ties between the pedagogical province and the Roman Catholic Church. Knecht succeeds in this, but for him the benefits of his time at Mariafels go beyond those intended by his Castalian Masters. From Father Jacobus he learns the value of history. He learns to think about himself and his society in a new light. He learns, as he did with Plinio, to question cherished Castalian assumptions. Knecht also teaches in his relationship with Father Jacobus, allowing the latter to soften his rather jaundiced view of the pedagogical province and appreciate more deeply the beauty of the Glass Bead Game and Castalian culture.

H.H. has an opportunity to learn in a similar way but he does not make the most of this. The third chapter of the novel focuses on H.H.'s discussions with Lukas, a friend from his youth who is now a newspaper editor. Lukas had taken part in the World War and had published a book about this. H.H. has two lengthy conversations with Lukas. H.H. shares his views on the League and while Lukas adopts the posture of what H.H. sees as 'a well-meaning sceptic', he is willing to listen carefully and reflectively. Lukas feels he can relate very strongly to aspects of H.H.'s account, and in particular to the difficulties the latter is having in developing his history. Lukas notes that while he had thought his war experiences were vivid and clear, when he came to write about them they were 'all immeasurably remote, only a dream, were not related to anything and could not really be conceived' (p. 56). When H.H. asks him how he was able to write the book despite these difficulties, Lukas replies: 'It was only possible for me to do it ... because it was necessary. I either had to write the book or be reduced to despair; it was the only means of saving me from nothingness, chaos and suicide' (p. 57). ${ }^{4}$

In their second conversation, Lukas issues a warning about H.H.'s apparent fixation on Leo. Lukas and H.H. discover that someone with the surname Leo is living not too far away. Lukas urges H.H. to go and see this Leo, in the hope that H.H. may learn something about the Leo he once knew. Lukas has, however, already said to H.H.: 'Listen, you continually come back to the episode with the servant Leo. I do not like it; it seems to be an obstacle in your way. Free yourself, throw Leo overboard; he seems to be becoming a fixed idea' (pp. 58-59). H.H.'s response, to himself (at the end of the chapter), is emphatic: 'I could just as much throw my head or my stomach overboard to get rid of them!' (p. 62). 'Dear God', he pleads, 'help me a little' (p. 62). H.H. fails to heed Lukas' warning here. By the end of the book, 'Leo' - both as a person and as an idea - still retains his grip on H.H. 'Leo' is the ideal, and it is the Leo half of the little double figure described at the end of the book that H.H. believes must dominate.

But for the 'Leo' part of H.H.'s self to grow, the 'I' that must disappear (p. 118) is an 'I' open to doubt. Martin Buber's (1958) discussion of 'I-Thou' and 'I-It' relations is helpful in elaborating on this point. For Buber, where the ' $\mathrm{I}$ ' in an 'I-It' relation appears as individuality and becomes conscious of itself as a subject, the 'I' in an 'I-Thou' relations appears as a person and becomes conscious of itself as 
subjectivity (p. 85). Individuality emerges by differentiation from other individualities; a person, by contrast, makes his or her appearance by entering into relations with other persons. In entering such relations we share in a reality, in a being that neither merely belongs to us not merely lies outside us. 'All reality', Buber says, 'is an activity in which I share without being able to appropriate for myself. Where there is no sharing, there is no reality' (pp. 85-86). To become a person, then, is to become conscious of oneself as 'sharing in being, as co-existing, and thus as being' (p. 86). Note, however, that this does not mean a person gives up his or her special being; it implies only that this being is not his or her observation-point. The special being - that is, the idea of the person as 'being different' - is 'simply there, the necessary and significant conception of being' (p. 87).

Individuality, on the other hand, revels in its special being or, rather, mostly in the fiction of its special being which it has made up for itself. For to know itself means basically for it (for the most part) to establish an authoritative apparent self, capable of deceiving it ever more and more fundamentally, and to procure for itself, in looking to and honouring this apparent self, the semblance of knowledge of its own being as it really is. Real knowledge of its being would lead it to self-destruction - to to rebirth. (p. 87)

Buber argues that no human being is either pure 'person' or pure 'individuality'. Every human being lives in the twofold 'I'. Nonetheless, there are humans who are 'so defined by person that they may be called persons' and others 'so defined by individuality that they may be called individuals'. 'True history', Buber maintains, 'is decided in the field between these two poles' (p. 88).

H.H. provides a fascinating case-study in the light of Buber's theoretical framework. On the one hand, it might seem as if he wishes to surrender his individuality in favour of becoming, in Buber's terms, a person. He appears to wish to enter into a relation with Leo and thereby to develop an awareness of his own subjectivity. Yet, the relation into which he wishes to enter is one with a reified 'Leo'. It is Leo as represented in the wax figure; Leo as an idea - or, almost, Leo as an 'It'. H.H., despite seeking absorption into the image or idea of Leo, retains a certain attachment to the notion that only by doing this will his individuality be assured. His relationship with Leo is not one of two persons seeking through dialogue to advance themselves spiritually and affirm their humanity. There is a fundamental tension between Leo as authority figure and H.H. as (ultimately) compliant subject that is never resolved in the novel. H.H. lacks the educational development necessary to see beyond the idea of Leo as a means to and end. Buber, in Between Man and Man, argues that '[t]he relation in education is one of pure dialogue' (1961, p. 125). Leo becomes a kind of release valve; a means through which H.H. can relieve himself of pressures and uncertainties, rather than a person with whom he can enter into a genuinely dialogical relationship. H.H., in his eagerness to find a solution to his existential crisis, does abandon what Buber would call his 'special being' - his way of 'being different' - in the interests of addressing a quite specific problem of being. An educational response demands that he examine himself in relation to others and the world, but he cannot take this step.

Leo, it seems to me, while admirable in many respects (and I am speaking here of both the person Leo, as depicted in the book, and the idea of Leo), is a little too certain of his certainties. He lacks some of the warmth and vulnerability that gives other characters in Hesse's literary worlds a distinctively human strength. Leo, the reader feels, could never form the sort of friendship with H.H. that Govinda is able to forge with Siddhartha (in Hesse, 2000a). The connection between Narcissus and 
Goldmund (in Hesse, 1968a) provides another example. Narcissus and Goldmund are very different, yet there is an underlying bond of mutual respect that does not seem to be present in H.H.'s relationship with Leo. There is perhaps potential for a relationship of this kind to develop between H.H. and Lukas, but this is not allowed to grow. H.H. is committed, in a peculiarly uncritical way, to his reintegration with the League. He is too 'self-centred', despite his humiliation in front of the crowd of officials, and this restricts his ability to come to know himself in other ways. He does not see that knowing himself might require the growth of critical, dialogical friendships with others and a certain decentering of the self he seeks to become ('Leo').

The Glass Bead Game (Hesse, 2000b) again provides an insightful point of contrast. Knecht has a deep respect for the Game and the traditions associated with it. Yet he is also able to reflect critically on this - to love the Game while simultaneously struggling with it, as Freire might have put it (Freire and Shor, 1987). Knecht's willingness to question is evident even when he meets and interacts with others he admires, such as Father Jacobus and the Music Master. In his younger life, Joseph reveres the Music Master, but as he progresses through the Castalian education system he develops questions that demand answers. He does not simply accept what his elderly mentor has to say, but seeks to inquire of him and learn from him. H.H. lacks the crucial educative development that we see in Joseph Knecht, and this is why his belief that he has found the answer to his existential angst is flawed. Leo becomes, in Tusken's words, a 'father figure' for H.H. and while Hesse's message may have been that Leo is a guide who serves 'only until his follower is mature' (Tusken, 1992, p. 632), H.H.'s excessive reliance on faith shows how much further he has to go on his educational journey before reaching the level of maturity to which Tusken refers.

\section{CONCLUDING COMMENTS}

Hermann Hesse was a man of the West who also looked to the East for spiritual and intellectual guidance. For Hesse, as for H.H., the East was much more than a geographical location. It was an ideal toward which all who seek to know themselves must travel, each in their own way. H.H.'s path in The Journey to the East involves the overcoming of despair through confession and absorption into the higher self represented by the figure of Leo. H.H., I have argued, does not follow his journey as far Hesse came to believe we could. The missing element in the resolution of his crisis is a well developed awareness of the importance of education. It was not until his final novel, The Glass Bead Game, that Hesse was able to convey in a convincing and well rounded manner his position on the significance of education for all journeyers to the East. This involved a critical return to his Western cultural roots and a probing reconsideration of some of the elitist and egocentric assumptions underpinning journeys of the kind undertaken by H.H. in The Journey to the East. The lessons to be learned from The Glass Bead Game - those pertaining to the intertwining of self with society, the need for questioning and critique, the value of dialogue, the acceptance of uncertainty, and the necessarily lifelong process of education - are as relevant today as they were in Hesse's time. There is much to be gained from those lessons as we reflect, now and in the future, on how best to travel to 'the East', wherever that may be. 
Correspondence: Peter Roberts, School of Educational Studies and Human Development, College of Education, University of Canterbury, Dovedale Avenue, Private Bag 4800, Christchurch 8140, New Zealand.

E-mail: peter.roberts@canterbury.ac.nz

\section{ACKNOWLEDGEMENTS}

I wish to thank two anonymous reviewers for their very helpful comments on an earlier version of this paper. 


\section{NOTES}

1 Dostoevsky’s portrait of a new 'Russian man' in The Brothers Karamazov (Dostoevsky, 1991) and The Idiot (Dostoevsky, 2001) was, Hesse believed, already beginning to influence German youth. In Antosik's words, Dostoevsky's characters were 'all dangerous, amoral, and half-mad' and 'erased every distinction between the values necessary for the well-being of the individual and society' (Antosik, 1978, p. 63). Hesse saw in Dostoevsky the interplay of opposites that would reappear, in new ways, in his own work: love and hate, reason and faith, joy and despair, compassion and cruelty. In the twentieth century these themes would be played out not just within and between individuals but across whole nations. Dostoevsky, through what Bakhtin (1984) calls the 'polyphonic' structure of his novels, allowed the struggles between old and new values to come to life more vividly than any other nineteenth century literary figure.

2 Nietzsche's influence can be detected in several of Hesse's books. While some of Hesse's novels, such as Demian (Hesse, 1999), echo the heroic, self-overcoming tendencies in Nietzsche's thought, others pay tribute to the tragic nature of Nietzsche's prophetic mind. The narrator in the first part of Steppenwolf, for example, observes: 'A nature such as Nietzsche's had to suffer our present ills more than a generation in advance. What he had to go through alone and misunderstood, thousands suffer today' (Hesse, 1965, p. 28). Nietzsche's presence can also be felt in The Journey to the East and The Glass Bead Game. Of particular interest is the character of Fritz Tegularius in The Glass Bead Game. Tegularius, whom Hesse based on Nietzsche, emerges as a nervous, socially inept but brilliant figure a representative of what Hesse saw as possible for a closed, intellectually oriented social system of the future. In Fritz, readers can see both the strengths and the weaknesses of a utopian community like Castalia. Castalia provides safe soil for the cultivation of a rich intellectual and aesthetic life, but, by separating itself from the rest of the world, it remains brittle - in decay and ready to fall apart at any time.

3 This is consistent with the pattern of 'induction' frequently employed in cults, often with dangerous consequences. As Umberto Eco shows in his novel Foucault's Pendulum (Eco, 1989), it does not matter, in some ways, whether the views shared by members of a secret society or brotherhood are true; what matters is that those views be passed on, adhered to with conviction, and protected through the ages. Reason of a kind, Eco demonstrates, can co-exist with a certain form of madness. Those who step outside the circle of reasoning that gives the lives of members in such societies their meaning can suffer severe punishment and even death.

4 These thoughts mirror those Hesse himself had at different moments of his writing career. He endured periods of despair, and had to struggle to complete some of his books. The first part of Siddhartha was composed relatively quickly and easily but progress then came to abrupt halt. Hesse was deeply despondent, convinced he had to set the novel aside until he had experienced personally what he wanted to depict in fictional form. More than two years would pass before he was able to complete the novel (Morris, 2000, pp. xv-xvii). The writing of The Glass Bead Game was even more tortured, emerging in fits and starts over a period of more than ten years (Field, 1968; Mileck, 1970). Writing for Hesse was necessary - in enabling him to clarify his ideas, to follow his path on the journey to the East, and to mitigate some of the effects of psychological distress - but it was not sufficient in providing a lasting solution to his despair and he continued to struggle with this for much of his life. 


\section{REFERENCES}

Antosik, S. (1978) The confession of a cultural elitist: Hesse's homecoming in Die Morgenlandfahrt, The Germanic Review, 53 (1), pp. 63-68.

Bakhtin, M. (1984) Problems of Dostoevsky's Poetics, ed. and trans. C. Emerson (Manchester, Manchester University Press).

Barrow, R. (2004) Language and character, Arts and Humanities in Higher Education, 3, pp. 267-279.

Buber, M. (1961) Between Man and Man, trans. R.G. Smith (London, The Fontana Library). (Original work published 1929-1938)

Buber, M. (1958) I and Thou, $2^{\text {nd }}$ (revised) edn., trans. R.G. Smith (Edinburgh, T. \& T. Clark). (Original work published 1923)

Carr, D. (2005) On the contribution of literature and the arts to the educational cultivation of moral virtue, feeling and emotion, Journal of Moral Education, 34, 137-151.

Crenshaw, K.O. \& Lawson, R.H. (1972) Technique and function of time in Hesse's Morgenlandfahrt: a culmination, Mosaic, 5 (3), pp. 53-59.

Cunningham, A. (2001). The Heart of What Matters: The Role for Literature in Moral Philosophy. (Berkeley, CA, University of California Press).

Dostoevsky, F. (1991) The Brothers Karamazov, trans. R. Pevear \& L. Volokhonsky (New York, Vintage).

Dostoevsky, F. (2001) The Idiot, trans. R. Pevear \& L. Volokhonsky (London, Granta).

Eco, U. (1989) Foucault's Pendulum, trans. W. Weaver (London, Secker and Warburg).

Field, G.W. (1968) On the genesis of the Glasperlenspiel, The German Quarterly, 41 (4), pp. 673-688.

Freire, P. \& Shor, I. (1987) A Pedagogy for Liberation (London, Macmillan).

Gribble, J. (1983) Literature and the education of the emotions, in: Literary Education: A Revaluation, pp. 95-113 (Cambridge, Cambridge University Press).

Gropper, E.C. (1970) Literature for the restive: Hermann Hesse's books, The English Journal, 59 (9), pp. 1221-1228.

Gropper, E.C. (1972) The disenchanted turn to Hesse, The English Journal, 61 (7), pp. 979-984.

Helt, R.C. (1996) '... A Poet or Nothing at All': The Tübingen and Basel Years of Hermann Hesse (Providence, RI, Berghahn Books).

Hepburn, R.W. (1972) The arts and the education of feeling and emotion, in: R.F. Dearden, P.H. Hirst \& R.S. Peters (eds.) Education and Reason, pp. 94-110 (London, Routledge and Kegan Paul).

Hesse, H. (1956) The Journey to the East, trans. H. Rosner (New York, The Noonday Press) (Original work published 1932)

Hesse, H. (1965) Steppenwolf, trans. B. Creighton, revised W. Sorell (London, Penguin). (Original work published 1927)

Hesse, H. (1968a) Narcissus and Goldmund, trans. U. Molinaro (New York, Picador). (Original work published 1930)

Hesse, H. (1968b) Beneath the Wheel, trans. M. Roloff (New York, Picador). (Original work published 1906)

Hesse, H. (1969) Peter Camenzind, trans. M. Roloff (New York, Picador). (Original work published 1904)

Hesse, H. (1970) Poems, trans. J. Wright (London, Jonathan Cape). (Original poems published 18991921)

Hesse, H. (1973) Strange News From Another Star and Other Tales, trans. D. Lindley (London, Jonathan Cape). (Original work published 1919)

Hesse, H. (1974a) Reflections, selected from his books and letters by V. Michels, trans. R. Manheim (New York, Farrar, Straus and Giroux).

Hesse, H. (1974b) Stories of Five Decades, trans. R. Manheim (with two stories translated by D. Lindley), ed. T. Ziolkowski (Frogmore, St Alban's, Herts, Triad/Panther).

Hesse, H. (1974c) It the War Goes On ... Reflections on War and Politics, trans. R. Manheim (London, Picador). (Original work published 1914/1946)

Hesse, H. (1978) My Belief: Essays on Life and Art, trans. D. Lindley (with two essays translated by R. Manheim), ed. T. Ziolkowski (London, Triad/Panther).

Hesse, H. (1982) Pictor's Metamorphoses and Other Fantasies, trans. R. Lesser, ed. T. Ziolkowski (New York, Farrar, Straus and Giroux).

Hesse, H. (1985) Wandering: Notes and Sketches, trans. J. Wright (London, Triad/Panther).

Hesse, H. (1999) Demian, trans. M. Roloff \& M. Lebeck, introduction by T. Mann (New York, Perennial Classics). (Original work published 1919) 
Hesse, H. (2000a) Siddhartha, trans. S.C. Kohn, introduction P.W. Morris (Boston, Shambhala). (Original work published 1922)

Hesse, H. (2000b) The Glass Bead Game, trans. R. Winston \& C. Winston (London, Vintage). (Original work published 1943)

Jollimore, T. \& Barrios, S. (2006) Creating cosmopolitans: the case for literature, Studies in Philosophy and Education, 25, pp. 263-283.

Joyce, J. (1990) Ulysses (New York, Vintage).

Katz, M. (1997) On becoming a teacher: May Sarton’s The Small Room, Philosophy of Education 1997 (Urbana-Champaign, IL, Philosophy of Education Society). Retrieved 29 October 2001 from: http://w3.ed.uiuc.edu/EPS/PES-Yearbook/97_docs/katz.html

Kierkegaard, S. (1989) The Sickness Unto Death, trans. A. Hannay (London, Penguin). (Original work published 1849)

Leary, T. (1986) Artificial intelligence: Hesse’s prophetic ‘Glass Bead Game’, Mosaic, 19 (4), pp. 195207.

Middleton, J.C. (1957) Hermann Hesse’s Morgenlandfahrt, Germanic Review, 32 (4), pp. 299-310.

Mileck, J. (1970) Das Glasperlenspiel: Genesis, manuscripts, and history of publication, The German Quarterly, 43 (1), pp. 55-83.

Morris, P.W. (2000) Introduction, in: Hesse, H. Siddhartha, trans. S.C. Kohn (Boston, Shambhala). (Original work published 1922)

Norton, R.C. (1968) Hermann Hesse's criticism of technology, The Germanic Review, 43, pp. 267-273.

Novitz, D. (1987) Knowledge, Fiction and Imagination (Philadelphia, PA, Temple University Press).

Nussbaum, M. (1990) Love's Knowledge: Essays on Philosophy and Literature (New York, Oxford University Press).

Nussbaum, M. (1995) Poetic Justice: The Literary Imagination and Public Life (Boston, MA, Beacon Press).

Palmer, F. (1992) Literature and Moral Understanding: A Philosophical Essay on Ethics, Aesthetics, Education, and Culture (Oxford, Clarendon Press).

Peters, M. (1996) Cybernetics, cyberspace and the university: Herman Hesse's The Glass Bead Game and the dream of a universal language, chapter 9 in: Poststructuralism, Politics and Education, pp. 159-176 (Westport, CT, Bergin and Garvey).

Plato (1974) The Republic, $2^{\text {nd }}$ edn., trans. H.D.P. Lee (Harmondsworth, Penguin).

Roberts, P. (2005) Freire and Dostoevsky: uncertainty, dialogue and transformation, Journal of Transformative Education, 3, pp. 126-139.

Roberts, P. (2007) Conscientisation in Castalia: a Freirean reading of Hermann Hesse's The Glass Bead Game, Studies in Philosophy and Education, 26 (6), pp. 509-523.

Schwarz, E. (1970) Hermann Hesse, the American youth movement, and problems of literary evaluation, PMLA, 85 (5), pp. 977-987.

Sears, J.T. (1992) The second wave of curriculum theorizing: labyrinths, orthodoxies, and other legacies of the glass bead game, Theory Into Practice, 31, pp. 210-218.

Sichel, B.A. (1992) Education and thought in Virginia Woolf's To the Lighthouse. Philosophy of Education 1992 (Urbana-Champaign, IL, Philosophy of Education Society). Retrieved 2 Feburary 2005 from: http://w3.ed.uiuc.edu/EPS/PES-Yearbook/92_docs/Sichel.html

Siegel, H. (1997) Teaching, reasoning, and Dostoevsky’s The Brothers Karamazov, in: Rationality Redeemed? Further Dialogues on an Educational Ideal, pp. 39-54 (New York and London, Routledge).

Solomon, R.C. (1986) Literacy and the education of the emotions, in: S. de Castell, A. Luke, \& K. Egan (eds.) Literacy, Society, and Schooling: A Reader, pp. 37-58 (Cambridge, Cambridge University Press).

Spivey, T.R. (1970) The reintegration of modern man: An essay on James Joyce and Hermann Hesse, Studies in the Literary Imagination, 3 (2), pp. 49-64.

Swales, M. (1978) The German Bildungsroman from Wieland to Hesse (Princeton, N.J., Princeton University Press).

Tillich, P. (1952) The Courage to Be (New Haven, NJ, and London, Yale University Press).

Timpe, E.F. (1969) Hermann Hesse in the United States, Symposium, 23 (1), pp. 73-79.

Tusken, L.W. (1992) A mixing of metaphors: masculine-feminine interplay in the novels of Hermann Hesse, Modern Language Review, 87 (3), pp. 626-635.

Wands, B. (1999) Digital art: a Glass Bead Game? Leonardo, 32 (5), pp. 349-351.

Weston, M. (2001) Philosophy, Literature and the Human Good (London and New York, Routledge).

Wilde, L. (1999) The radical appeal of Hermann Hesse's alternative community, Utopian Studies, 10 (1), pp. 86-97. 
Zigler, R.L. (1994) Reason and emotion revisited: Archilles, Arjuna, and moral conduct, Educational Theory, 44 (1), pp. 63-78. 